simply having to take the patient to and from the equipment created new logistical problems within the hospital.

Howell is neither a technological apologist nor a wistful romantic. Technology changed the nature of the hospital during those decades, adding to its costs and making the surroundings less domestic and familiar. In many instances it changed neither the diagnosis nor the treatment the patient received, but sometimes it could, as when acute appendicitis was part of the differential diagnosis and when white blood cell counts mattered. Analysing a large random sample forces Howell to look at the ordinary, and it is at this level that his book is both intriguing and frustrating. Because his hospitals sometimes responded differently to various new technologies, he is acutely aware of the danger of generalizing from only two institutions. His original project aimed to compare the United Kingdom and the United States; the United
Kingdom is now reserved for a second volume and various US issues - about costs, or the development of paramedical groups, for example - are only cursorily examined. We are shown how the principles of accountancy began to influence hospital finance (the managerial revolution is of long duration), but the counterintuitive revelation that employment costs apparently became less important between 1898 and 1920 (in one hospital, at least) passes without comment.

In his conclusion, Howell relates his historical research to contemporary ethical and economic debates. These lessons are not terribly surprising, but his early twentieth-century portrait is fresh and important, as an analysis of medical practice just coming to grips with the technological world.

W. F. Bynum is at the Wellcome Institute for the History of Medicine, 183 Euston Road, London NW1 2BN, UK.

\title{
The shape of things to come
}

Ziauddin Sardar

Visions of the Future: The Distant Past, Yesterday, Today and Tomorrow. By Robert Heilbroner. Oxford University Press: 1995 . Pp. 133. \$19.95.

The End of the Future: The Waning of the High-Tech World. By Jean Gimpel. Adamantine: 1995. Pp. 125. £32.50 (hbk); $£ 14.95$ (pbk).

THINKING about the future is a tricky and hazardous business. Tricky because our conventional way of thinking does not normally incorporate the future - we consciously have to strive to imagine what the future may hold, what anticipated and unexpected possibilities lurk on the distant horizon. Hazardous because the probability of getting one's forecasts wrong is very high.

It is not surprising then that both Robert Heilbroner and Jean Gimpel are rather cautious about making any predictions. Heilbroner is concerned chiefly with the way we think about the future and how this thinking has itself changed. Gimpel, on the other hand, focuses largely on the failures, unfulfilled promises and our misplaced optimism that technology would usher in a more humane and sane future. Both are economical with their analysis but nevertheless provide a punchy and thought-provoking examination of our inability to comprehend the future.

Heilbroner takes us through the history of humanity, as seen from the perspective of the West, at an exhilarating pace. The distant past, covering 150,000 years to yesterday, is marked by a wide range of diversity in all spheres of human existence, with one exception: its view of the future. Until about 250 years ago, when yesterday began, the future was static; the present simply continued endlessly as there were no self-generating changes. The future alters with the arrival of capitalism, Western science and technology and popular political movements. Suddenly, endless progress becomes the main theme of the future. While the distant past continued for most of humanity, a new era appeared in the nations of the West. But faith in perpetual progress is now waning. Our trust in science and technology has been shaken. We are more sceptical about our political institutions and their ability to deliver a just and equitable society. Capitalism, we have learned, says Heilbroner, is only good for the rich. In the United States alone, the number of people living in poverty rose from 23 million to 35 million between 1975 and 1991, whereas the number of millionaires increased from 642 to 60,667 . So tomorrow demands that we re-examine our basic assumptions.

Whereas Heilbroner asks that we rethink our economic principles, political institutions and the nature of our science and technology, Gimpel argues for a new way of seeing technological development. The crisis in the West is largely due to our disenchantment with a host of technologies that were seen purely in utopian terms. Such notions as the 'electronic cottage', intelligent and perfect computers and space travel were seen as panaceas that would rescue humankind from its follies. Instead, they have turned out to be mirages. Indeed, we are going backwards into the future: concerned citizens are giving up their cars for bicycles, we increasingly prefer cotton, silk and linen to man-made fibres, and concrete is being abandoned in favour of timber-framed housing.

All this means that the West has reached a technological plateau. From now on, technologies may seem to be better, faster and more promising, but in reality they would not improve our lives, or deliver the greatest material benefits to most of humanity, or make us more happy. Moreover, we can already discern a marked decline in technological innovation. The belief in the power of technology to rescue our future is therefore dangerously obsolete.

The future is thus waiting to explode. We can no longer be sure, Heilbroner asserts, that we will actually survive. The only way to do so is to think more concretely and imaginatively about the future. In particular, we must focus our thinking about the future on three principles. First, we must ensure that we achieve a secure terrestrial base for life. This means abandoning many cherished notions about materialism, progress and perpetual advances in science and technology. Second, we must "find ways of preserving the human community as a whole against its warlike proclivities". This requires abandoning naked capitalism for more humane economics and seeking more appropriate models of governance. Third, the distant future must take us towards a much deeper and more abiding respect for 'human nature' and this can be ensured only if we make total respect for human dignity a prime focus in our contemporary cultural and educational concerns.

Gimpel does not offer a prescription for the future. He simply asserts that we have reached the end of the golden age of Western science and technology. And the West, like all other civilizations, as ibn Khaldun and others have predicted, must decline in order to rise again in some far distant future. The present phase of the cycle of rise and decline of civilizations favours the Asian civilizations. The near future, the twenty-first century, belongs to Asia in general and to China in particular. The centre of world trade has already moved to the Pacific Basin. The nations of the Far East are growing at a phenomenal annual rate of eight per cent - and there is no indication that this will slow down in the next decades. The growth of Asia means the end of 'white supremacy' and the return to a future of a thousand years ago. "China is at the beginning of a cycle that could last a millennium, while western civilization stands at the end of a cycle that is already 1,000 years old", says Gimpel. Who could argue with that?

Ziauddin Sardar, a consulting editor of Futures and visiting professor of science and technology policy at Middlesex University, is at 1 Orchard Gate, London NW9 6HE, UK. 